\title{
Efficiency of n-Octyl-Acetate, 2-Heptanone and Citronellal in Repelling Bees from Basil (Ocimum sellowii - Labiatae)
}

\author{
Darclet Teresinha Malerbo-Souza ${ }^{*}$ and Regina Helena Nogueira-Couto \\ Departamento de Ciências Agrárias; Centro Universitário Moura Lacerda; Av. Dr. Oscar de Moura Lacerda, 1520; \\ 14076-510; Ribeirão Preto - SP - Brazil
}

\begin{abstract}
The objective of this study was to test repellent substances for honey bees, Apis mellifera, for basil, Ocimum sellowii, and to study the most frequent insects in this crop as well as its behaviors. The frequency of honey bees did not decrease with the application of n.octyl.acetate, citronellal and 2.heptanone, used as repellents, in the concentrations 2.5, 5.0, 7.5 and $10.0 \%$ diluted in water. However, when the products (20\%) were diluted in water (75\%) and glycerine (5\%) were effective in repelling those bees of the basil flowers for a period of 20 minutes. The flower lasted, on average, $30 \mathrm{~h}$ from the bud phase until the flower withered. The flowers number opened by inflorescence was, on average, 5.65 flowers, and the inflorescence presented, on average, 160 flowers-buds. The basil was visited mainly for the honey bee (98.0\%), followed by Augochloropsis electra bee - Halictidae (2.0\%) and visits sporadics of Diptera and Lepidoptera, collected only nectar. The honey bee frequency increased during the day to 14:00, decreasing soon after, accompanying the curve of the temperature sets registered in the experiment days.
\end{abstract}

Key words: Repellent, Apis mellifera, basil, Ocimum sellowii, pollination, insects

\section{INTRODUCTION}

There are several means to attract bees for the cultures that need cross pollination .(Free, 1962; Weaver et al., 1964; Free, 1968; Butler and Calum, 1969; Waller, 1970; Woyke, 1981; Ohe and Praagh, 1983; Mayer et al., 1989; Currie et al., 1992; Naumann et al., 1994; Ambrose et al., 1995; Malerbo-Souza, 1996) In some cases the presence of the honey bees becomes an uncomfortable one. As example can be mentioned the culture of the yellow passion fruit (Passiflora edulis $f$. flavicarpa Deg.) where these bees are considered as plague in certain areas. In these cases would be necessary substances that repel the bees for a time (Salis, 1987).

Several substances have been studied to repel the bees (Harpaz and Lensky, 1959; Grout, 1963; Atkins Jret al., 1975ab, 1978; Attri and Singh, 1978; Bocquet et al., 1982; Stark, 1982; Wimmer, 1983; David and Somasundaran, 1985; Moreti, 1989). Blum et al. (1978) observed that the concentrade mixture of $n$.octyl.acetate and benzil acetate tested in sunflower flowers were much more effective in repelling bees than the mixture of iso-pentil-acetate and 2.heptanone. High concentrations of iso-pentilacetate and 2.heptanone, sprayed in colza and bean stonemasons reduced the foraging of the bees $80 \%$ and $40 \%$, respectively; however, after 30 minutes, the repellence had disappeared (Free, 1987). Free et al. (1989) concluded that component $n$.octyl.acetate was the best repellent to the bees than the benzil acetate, 2.nonanol, fenol and iso-pentil-acetate.

*Author for correspondence 
In this work a Ocimum culture was used to attract the honey bees. In Brazil, this culture is cultivated as aromatic plant and its flowerage extends for practically the whole year. Thus, the aim of the present trial was to test repellents for the honey bees, Apis mellifera, in the culture of basil, Ocimum sellowii, and to study the frequency and behaviour of insects on these flowers as well as determination of the collection time and type of most frequent bees.

\section{MATERIALS AND METHODS}

The present experiment was carried out at Faculdade de Ciências Agrárias e Veterinárias (FCAV), UNESP, Jaboticabal, SP, Brazil. The experimental site is located at an altitude of $595 \mathrm{~m}$ with the following geographical coordinates: $21^{\circ} 15^{\prime} 22^{\prime \prime} \mathrm{S}$ and $48^{\circ} 18^{\prime} 68^{\prime \prime} \mathrm{W}$ and the mean temperature of the region is $21^{\circ} \mathrm{C}$. The climate is subtropical with average annual precipitation of $1.431 \mathrm{~mm}$. A basil stonemason of $20.0 \times 1.0 \mathrm{~m}$ located in the Horticulture Section of FCAVJ/UNESP was used.

\section{REPELLENTS}

In first stage, $n$-octyl-acetate, 2.heptanone and citronellal (SIGMA) in concentrations of 2.5, 5.0, 7.5 and $10.0 \%$ diluted in water were sprayed at two different times (10:00 $\mathrm{h}$ and 14:00 h) with manual sprayer of gardening. In a second stage the products $(20 \%)$ were diluted in water $(75 \%)$ and glycerol (5\%) and sprayed at 9:00 o'clock.

The frequency of the honey bees, Apis mellifera in the flowers was obtained through counting every five minutes before and after the application of the repellents with four replications for each product in each used concentration. Two treatments were used for each product to observe the repellence for honey bees: $\mathrm{T} 1=$ area of $5.0 \times 1.0 \mathrm{~m}$ no sprayed and $\mathrm{T} 2=$ area of $5.0 \times 1.0 \mathrm{~m}$ sprayed with the repellent. Throughout the flowering period the culture was kept under observation and the following parameters were studied:

\section{FLOWERS}

(1) development period of 100 flowers (three replications) from the bud phase until the flower withered;

(2) average number of flowers opened in 20 inflorescences, counted at 12:00 $\mathrm{h}$ with four replications;

(3) quantity of total soluble carbohydrates (average values $-\mu \mathrm{g} /$ flower) in the nectar of flowers collected at 8:00, 10:00, 12:00 and 14:00 $\mathrm{h}$ with four replications, in flowers of the same age, according to the Roberts method (1977).

\section{INSECTS}

(1) the frequency of visits of more frequent insects was obtained through counting during first five minutes each interval (8:00 to $17: 00 \mathrm{~h})$ with four replications;

(2) time and type of visit (for pollen and or nectar collection) of more frequent insects with thirty replications;

(3) the relationship occurrence between temperature sets with the frequency of visits during the day.

The data were analyzed by means of Analyses of Variance in the program ESTAT that includes Tukey Test for comparison of averages of whole variables and Analyses of Regression, to test each variable in the time. The data were considered at the level of $5 \%$ of significance.

\section{RESULTS AND DISCUSSION}

\section{REPELLENTS}

The frequency of the visits of the honey bees did not decrease when sprayed repellents n.octyl.acetate, 2.heptanone and citronellal diluted in water in concentrations 2.5, 5.0, 7.5 and $10.0 \%$ independent of the hours (at 10:00 and 14:00 h). When the products $(20 \%)$ were diluted in water $(75 \%)$ and glycerol (5\%), it was observed that citronellal repelled larger number of honey bees significantly $(29.40 \%)$ followed by $n$.octyl.acetate $(19.35 \%)$ and 2.heptanone $(16.45 \%)$ compared to the control treatment. Free et al. (1989) observed that n.octyl.acetate was the most effective repellent for honey bees. Citronellal, n.octyl.acetate and 2.heptanone were effective in repelling honey bees of the basil flowers for a period of 20 minutes (Fig. $1)$.

\section{FLOWERS}

The basil flowering lasted on average $30 \mathrm{~h}$ from the bud phase until the flower withered. The number of flowers opened by inflorescence was on average 5.65 flowers and the inflorescence presented 160 
flowers-buds, on average. The mean quantity of total soluble carbohydrates in the nectar of the basil flower was on average $10.68 \pm 2.6 \mu \mathrm{g}$ of sucrose per flower increasing during the day: $8.73 \pm 3.4 \mu \mathrm{g}$ at $8: 00 \mathrm{~h}, 8.17 \pm 2.2 \mu \mathrm{g}$ at $10: 00 \mathrm{~h}, 12.26 \pm 1.5 \mu \mathrm{g}$ at $12: 00 \mathrm{~h}$ and $13.55 \pm 1.1 \mu \mathrm{g}$ of sucrose per flower at $14: 00 \mathrm{~h}$.

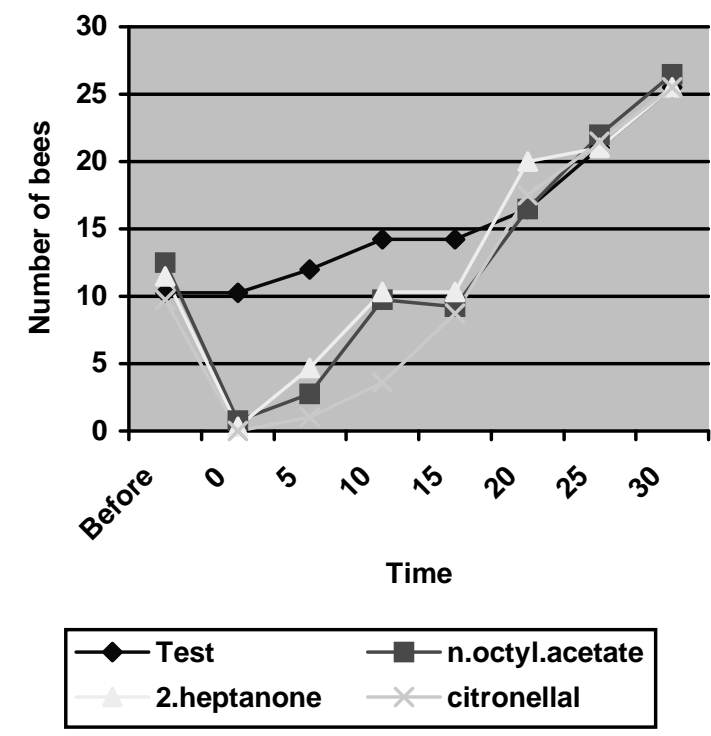

Figure 1 - Mean frequency of the honey bees, Apis mellifera L., during the day in basil flowers, Ocimum sellowii, with the application of n.octyl.acetate, citronellal and 2.heptanone diluted in water and glycerine at 9:00 $\mathrm{h}$ in Jaboticabal, 1997.

\section{INSECTS}

The basil was visited mainly by the honey bee $A$. mellifera (98\%), followed by the native bee Augochloropsis electra-Halictidae (2\%) and sporadics visits of Diptera and Lepidoptera. Those insects collected only nectar in the culture and delayed of 1 to 3 seconds in each flower. In São Paulo, Brazil, the bees observed in this plant species were A. mellifera, Trigona spinipes, Tetragonisca angustula, Nannotrigona testaceicornis and Paratrigona subnuda collecting nectar and pollen (Pirani and Cortopassi-Laurino, 1993). The frequency of the honey bee increased in elapsing of the day until 14:00 $\mathrm{h}$ decreasing soon after accompanying the curve of the temperature sets registered in the experiment days (Fig. 2) and also accompanying the increase in nectar concentration of the flowers.

The floral essences can present the same function of the nectar in the attraction of the pollinators. The basil, Ocimum basilicum (L.), has as main components of its essential oil, estragol and linalol. Another basil species, Ocimum gratissimum (L.) has eugenol as main component (Ladeira 1983). The essential oils of the basil (Ocimum sellowii) contain estragol, linalol, lineol, ancanfor, eugenol, cineol, pineno and timol (Teske and Trentini, 1995).

From the results it can be concluded that the citronellal, n.octyl.acetate and 2.heptanone were effective in repelling honey bees for a period of 20 minutes when diluted in water and glycerol. The basil culture were highly attractive for the honey bees, Apis mellifera, and the insects visited basil flowers for nectar collection only.

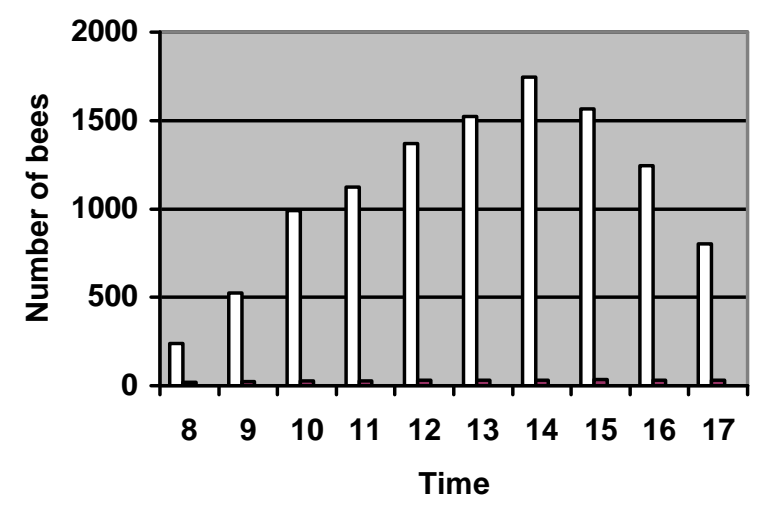

Figure 2 - Mean frequency of the honey bees, Apis mellifera L., during the day of 8:00 at 17:00 $\mathrm{h}$ in basil flowers, Ocimum sellowii in Jaboticabal, 1997.

\section{ACKNOWLEDGEMENTS}

We wish to thank CAPES, CNPQ and FAPESP, for financial support and to Prof. Dr. Manoel G. C. Masca. of Horticulture Section of FCAVJ/UNESP, for the concession of the experiment area and to the Center of Identification of Insects, Curitiba, PR, for the bees identification.

\section{RESUMO}

O objetivo do experimento foi estudar a polinização em manjericão (Ocimum sellowii), a fim de verificar 
sua atratividade para as abelhas Apis mellifera, os insetos mais freqüentes, bem como seus comportamentos e testar substâncias repelentes para as abelhas A. mellifera. A flor durou, em média, 30 horas, desde sua abertura até o murchamento. $\mathrm{O}$ número de flores abertas por inflorescência foi, em média, 5,65 flores, sendo que a inflorescência possuía, em média, 160 botões florais. O manjericão foi visitado quase que exclusivamente pela abelha $A$. mellifera africanizada $(98,0 \%)$, seguida pela abelha Augochloropsis electra-Halictidae $(2,0 \%)$ e visitas esporádicas de dípteros e lepidópteros, sendo que todos coletavam apenas néctar. A freqüência da abelha africanizada aumentou no decorrer do dia até às 14 horas, diminuindo em seguida, acompanhando a curva da temperatura ambiente registrada nos dias do experimento. As abelhas africanizadas demoraram de 1 a 3 segundos em cada flor. A frequiência das abelhas africanizadas não diminuiu com a aplicação dos produtos n.octyl.acetato, citronellal e 2.heptanona, usados como repelentes, nas concentrações 2,5, 5,0, 7,5 e 10,0\%, diluídos apenas em água. Entretanto, quando os produtos (20\%) foram diluídos em água $(75 \%)$ e glicerina (5\%), foram efetivos em repelir essas abelhas das flores de manjericão, por um período de 20 minutos.

\section{REFERENCES}

Ambrose, J. T.; Schultheis, J. R. and Bambara, S. B. et al. (1995), An evaluation of selected commercial bee attractants in the pollination of cucumbers and watermelons. Am. Bee J., 4, 267-271.

Atkins Jr., E. L.; Mcdonald, R. L. and Greywood-Hale, E. A. (1975a), Repellent additives to reduce pesticide hazards to honey bees: field tests. J. Environ. Ent., 4 : (2), 207-210.

Atkins Jr., E. L.; Mcdonald, R. L. and Mcgouern, T. D. et al. (1975b), Repellent additives to reduce pesticide hazards to honey bees: laboratory testing. J. Apic. Res., 14, 85-97.

Atkins Jr., E. L.; Kellum, D. and Atkins, K. W. (1978), Encapsulated methyl parathion formulation is highly hazardous to honey bees. Am. Bee J., 118 : (7), 483485.

Attri, B. S. and Singh, R. P. (1978), A note on the biological activity of the oil of Lantana camara $\mathrm{L}$. Indian J. of Entom., 39 : (4), 384-385.

Blum, M. S.; Fales, H. M. and Tucker, K. W. et al. (1978), Chemistry of the sting apparatus of the worker honeybee. J. Apic. Res., 17, 218-221.

Bocquet, J. Ch.; L'hotellier, M. and Fevre, F. et al. (1982),
A five-year study on the effect of deltamethrin on bees under natural conditions. In: Paper presented at $2^{\text {nd }}$. Symposium on Harmonization of Methods for Testing the Toxicity of Pesticides to Bees, Hohenhein.

Butler, C. G. and Calum, D. H. (1969), Pheromones of the honeybee - the secretion of the Nassanoff gland of the worker. J. Insect Physiol., 15, 237-244.

Currie, R. W.; Winston, M. L. and Slessor, K. N. (1992), Effect of synthetic queen mandibular pheromone sprays on honey bee (Hymenoptera: Apidae) pollination of berry crops. J. Econ. Entomol., 85, 1300-1306.

David, B. V. and Somasundaran, L. (1985), Syntetic pyrethroids - an evaluation of their potential effects nontarget organisms. Pesticides, 19 : (1), 9-12.

Free, J. B. (1962), The atractiveness of geraniol to foraging honey bees. J. Apic. Res., 1, 52-54.

Free, J. B. (1968), The conditions under which foraging honey bees expose their Nasonov glands. J. Apic. Res., 7, 139-145.

Free, J. B. (1987), Pheromones of social bees. Chapman and Hall.

Free, J. B.; Ferguson, A. W. and Simpkins, J. R. (1989), Honeybee responses to chemical components from the worker sting apparatus mandibular glands in field tests. J. Apic. Res., 7-21.

Grout, R. A. (1963), The hive and the honey bees. Hamilton: Dadant and Sons.

Harpaz, I. and Lensky, Y. (1959), Experiments on bee repellents. Bee World, 40 : (6), 146-53.

Ladeira, A. M. (1983), Plantas Medicinais. Secretaria de Agricultura e Abastecimento, São Paulo. Folheto n. 15, Jun.

Malerbo-Souza, D. T. (1996), Efeitos de atrativos $e$ repelentes sobre o comportamento forrageiro da abelha Apis mellifera. Tese de Doutorado, Faculdade de Ciências Agrárias e Veterinárias, Universidade Estadual Paulista, Jaboticabal, São Paulo.

Mayer, D. F.; Britt, R. L. and Lunden, J. D. (1989), Evaluation of BeeScent ${ }^{\mathrm{R}}$ as a honey bee attractant. Am. Bee J., 129, 41-42.

Moreti, A. C. C. C. (1989), Estudo sobre a polinização entomófila do girassol (Helianthus annuus L.) utilizando diferentes métodos de isolamento de flora. Tese de Doutorado, Escola Superior de Agronomia "Luiz de Queiroz", Universidade de São Paulo, Piracicaba, São Paulo.

Naumann, K.; Winston, M. L. and Slessor, K. N. et al. (1994), Synthetic honey bee (Hymenoptera: Apidae) queen mandibular gland pheromone apllications affect pear and sweet cherry pollination. J. Econ. Entomol., December, 1595-1599.

Ohe, W. and Praagh, J. P. (1983), Versuche zur Duftlenkung in Obstanlagen. Nordwetsdeutsche Imkerzeitung, 35, 100.

Pirani, J. R. and Cortopassi-Laurino, M. (1993), Flores e abelhas em São Paulo. São Paulo : EDUSP/FAPESP. 
Roberts, R. B. (1977), Method for assaying nectar sugar produces by plants and harvested by insects. J. of N. Y. Ent. Soc., 85 : (4), 197.

Salis, M.C. (1987), A cultura do maracujá na região de Araguari, MG. O problema da polinização. Monografia, Faculdade de Ciências Agrárias e Veterinárias, Universidade Estadual Paulista, Jaboticabal, São Paulo.

Stark, J. (1982), Sumicidin effects on pollinating insects. Vãxtskyddsrapporter. Apic. Abstr., 37 : (3), 199-203.

Teske, M. and Trentini, A. M. M. (1995), Compêndio de Fitoterapia. Herbarium Laboratório Botânico Ltda, Curitiba, Paraná.

Waller, C. D. (1970), Attracting honey bees to alfalfa with citral, geraniol and anise. J. Apic. Res., 9, 9-12.

Weaver, N.; Weaver, E. C. and Law, J. H. (1964), The attractiveness of citral to foraging honey bees. Prog. Rep. Texas Agric. Exp. Sta., 2324.

Wimmer, F. (1983), Colza, inseticidal treatments and the protection of bees. Phytoma, 346, 30-31.

Woyke, H. W. (1981), Some aspects of the role of the honeybee in onion seed production in Poland. Acta Horticulture, 111, 91-98.

Received: March 04, 2002; Revised: October 21, 2002; Accepted: July 22, 2003. 